\title{
СТАБИЛЬНОСТЬ ЗАКОНОДАТЕЛЬСТВА КАК ФАКТОР МОДЕРНИЗАЦИИ ЭКОНОМИКИ РФ *
}

\author{
(c) 2020 Джикия Михаил Давидович \\ ассистент кафедры конституционного и муниципального права \\ Волгоградский государственный университет, Россия, Волгоград \\ E-mail:dzhickiamd@volsu.ru
}

Автор отмечает, что существующее сегодня законодательство России вряд ли можно назвать стабильным, на всех уровнях власти ведется активная правотворческая деятельность, при этом, до сих пор не выработаны общие критерии оценки стабильности и качества нормативно-правовых актов, как следствие, нередко нормы права противоречат друг другу. Автором сделана попытка использования принципов системной методологии и институционального подхода к анализу роли стабильности законодательства в процессе модернизации экономики РФ, в современных условиях развития общества. В исследовании уточнено понятие «стабильность законодательства» с учетом ее двоякой природы воздействия на развитие общества и государства. Автором отмечается, что с точки зрения системного подхода, устойчивость одних элементов нивелирует волнообразное развитие других. В современном быстро изменяющемся мире, где один кризис сменяется другим, законодательство должно адекватно реагировать на изменения общественных отношений, одновременно сохраняя определённый уровень непротиворечивости, и тем самым поддерживать баланс между другими элементами системы. Автором выявлен ряд факторов влияющих на стабильность законодательства и предложен вариант их классификации. В исследовании описана роль оценки регулирующего воздействия (далее ОРВ) нормативных актов в достижении стабильности законодательства, а также предложены пути развития данного института в России. В статье выделены основные цели $\mathrm{OPB}$, среди которых ведущую роль играют расчет издержек населения, связанных с принятием новых законодательных требований, определение эффективного сочетания методов правового регулирования, расчет затрат предпринимателей на обучение персонала в связи с принятием новых законодательных требований, а также поиск путей поддержания делового климата и инвестиционной привлекательности на фоне принятия новых законодательных требований. На основании системного подхода обозначены ориентиры взаимодействия стабильной правовой основы с эффективными модернизационными процессами в экономике страны.

Ключевые слова: стабильность законодательства, модернизация правовой системы, факторы, ориентиры, оценка, воздействие, правовая система, противоречивость, качество, модернизация экономики, цифровизация.

\section{Введение}

Актуальность. Природа категории «стабильность законодательства» довольно противоречива, с одной стороны, в рамках радикального подхода стабильность может повлечь за собой стагнацию права, которое не способно будет реагировать на быстрые изменения в общественной жизни и экономическом развитии государства. С другой стороны, с точки зрения системного подхода, устойчивость одних элементов нивелирует волнообразное развитие других. Это означает, что в современном быстро изменяющемся мире, где один кризис сменяет- ся другим, законодательство РФ должно адекватно реагировать на изменения общественных отношений, одновременно сохраняя определённый уровень непротиворечивости, и тем самым поддерживать баланс между другими элементами системы. Вышесказанное повышает актуальность изучения стабильности законодательства, как фактора модернизации экономики России.

\section{Изученность проблемы}

Вопросы стабильности законодательства достаточно давно находятся в фокусе интересов отечественных правоведов, особую актуальность данный феномен приобрел после распада

* Исследование выполнено за счет гранта Российского научного фонда проект № 18-78-10075 
СССР - в 90-е годы прошлого столетия. Наиболее полное определение стабильности закона было дано в 2000 году в исследовании «Концепция стабильности закона» под редакцией В.П. Казимирчука. В свою очередь, большой вклад в изучение и анализ исследуемого явления также внесли И. А. Карасева [6] и В. А. Рыбаков [13]. В последние годы, стабильности законодательства свои работы посвящали М.Л.Давыдова, Д. Я.Примаков, В. В. Волков, А. В. Дмитриева [12], В.И.Павлов [10], С.Ф.Литвинова $[8,9]$ и др. В то же время, малоизученными остаются различные аспекты взаимовлияния стабильности законодательства с экономическими процессами, в частности с модернизацией экономики.

Целесообразность разработки темы исследования обусловлена важной ролью качественной правовой компоненты в реализации задач научно-технического развития РФ, обозначенных государством в рамках документов стратегического планирования.

Научная новизна заключается в попытке использования принципов системной методологии и институционального подхода к анализу роли стабильности законодательства в процессе модернизации экономики РФ в современных условиях развития общества.

Цель исследования состоит в определении места и роли стабильность законодательства в процессе эффективной модернизации экономики РФ.

Для достижения поставленной цели необходимо решение следующих задач исследования: обобщить и уточнить понятие стабильности законодательства с учетом ее двоякой природы воздействия на развитие общества и государства; выявить и систематизировать факторы, влияющие на стабильность законодательства; обозначить точки влияние стабильности законодательства на эффективность реализации процесса модернизации экономики РФ; обозначить ориентиры взаимодействия стабильной правовой основы с эффективными модернизационными процессами в экономике РФ.

Теоретическая и практическая значимость работы.

Наличие прогрессивного, непротиворечивого, социально обусловленного законодательства имеет существенное значение для осуществления технологической модернизации всех отраслей общественной жизни России. Практическая и теоретическая значимость работы состоит в попытке определения места и роли стабильность законодательства в процессе эффективной модернизации экономики РФ.

\section{Основная часть.}

Стабильность законодательства - это такое состояние социально обусловленных, непротиворечивых, согласованных правовых норм, которое характеризуются их прогрессивным воздействием на общественные отношения и в полной мере отвечает запросам общества на данном этапе его развития.

Вопросы стабильности законодательства достаточно давно находятся в фокусе интересов отечественных правоведов, особую актуальность данный феномен приобрел после распада СССР - в 90-е годы прошлого столетия. Наиболее полное определение стабильности закона было дано в 2000 году в исследовании «Концепция стабильности закона» под редакцией В.П., Казимирчука [7], где к основным признакам стабильности закона авторами отнесены:

- его социальная обусловленность;

- эффективность регулирования отношений;

- отсутствие противоречий;

- способность удовлетворять общественные интересы;

- высокий уровень юридической техники и языка закона.

Изучение различных аспектов стабильности законодательства не теряет актуальности и сегодня, ведь эффективность правовых норм, их социальная обусловленность и ориентированность на экономические реалии, по-прежнему играют существенную роль в модернизации всех сторон жизни общества.

При этом существующее на сегодня законодательство вряд ли можно назвать стабильным. Органы власти ведут активную правотворческую деятельность, при этом, до сих пор в России не выработаны общие критерии оценки стабильности и качества нормативно-правовых актов [3], как следствие, нередко нормы права противоречат друг другу.

Исследование факторов, влияющих на стабильность законодательства, целесообразно начинать с попытки классификации множества факторов по определенным критериям. Так, по времени возникновения можно рассматривать предзаконодательные и постзаконодательные, а по своей природе - правовые и социальные [4].

Существенными предзаконодательными 
факторами, влияющим на стабильность конкретного закона, можно считать содержательные изъяны языка закона и текстов нормативноправовых актов, в частности:

- нарушение соотношения общих и конкретных предписаний в текстах нормативных актов, которые выражаются в чрезмерной детализации норм и их декларативности (общем характере);

- сложные для толкования обороты использование нераскрытых терминов;

- избыточность нормативно-правовых актов (когда в тексте содержится текстовая информация, не содержащая правовых норм).

В качестве постзаконодательных факторов можно выделить:

1. Зачаточное состояние института регулирующего воздействия т.е. сбора мнений профессионалов и экспертных групп о проектах нормативных актов. Несколько лет назад по поручению Президента РФ, создан и функционирует специальный сайт - «Оценка регулирующего воздействия» (http://orv.gov.ru), но, он посвящен только нормативно-правовым актам разрабатываемым Министерством экономического развития. Функционал данного сайта позволяет проводить открытые публичные консультации по проектам нормативных актов с привлечением представителей бизнеса и экспертного сообщества.

Традиционно оценка регулирующего воздействия (далее ОРВ) ставит своими целями: расчет издержек предпринимателей связанных с принятием новых законодательных требований; определение эффективного сочетания методов правового регулирования; расчет затрат предпринимателей на обучение персонала в связи с принятием новых законодательных требований; поиск путей поддержания делового климата и инвестиционной привлекательности на фоне принятия новых законодательных требований. В интересах повышения стабильности законодательства, считаем необходимым распространить ОРВ на другие области государственного регулирования.

2. Отсутствие федеральной системы мониторинга правоприменения, как следствие, достаточно сложно проводить обобщение и анализ правоприменительной практики, невозможно эффективно осуществлять «настройку» нормативных актов (корректировать их по качества и количеству соответственно запросам реальной жизни). Приходится констатировать, что пока у государства, мало каналов обратной связи, через которые законодатель мог бы получать достоверную информацию о том, как работают законы и подзаконные нормативные акты.

Анализируя специфику правовых и социальных факторов определяющих уровень стабильности законодательства, отметим, что к правовым факторам относятся:

- особенности национальной правовой системы;

- уровень законодательной техники;

- состояние оценки регулирующего воздействия и др.

Социальные факторы стабильности законодательства определяются рядом условий, в которых оно (законодательство) создается и функционирует [14]:

- экономические реалии;

- национальные и политические условия;

- географические особенности региона (государства) и др.

Как известно, модернизация представляет собой изменение, усовершенствование, отвечающее современным требованиям [2].

С точки зрения системного подхода модернизация экономики - это комплекс определенным образом структурированных элементов (объекта и субъекта), наделенных интегративным качеством, позволяющим обеспечить снижение рисков, содействие принятию и реализации потенциальных преимуществ, направленных на качественное изменение структуры экономики РФ, при условии сохранения функциональной целостности элементов модернизационного процесса и наличия взаимодополняющей связи с внешней средой модернизационных изменений [1].

\section{Методология}

С самого начала следует отметить, что автор исследования применяет принципы системной методологии и институционального подхода к анализу роли стабильности законодательства в процессе модернизации экономики РФ в современных условиях развития общества. В соответствии с вышеупомянутыми методологическими подходами, стабильность законодательства российского государства служит решающим фактором для достижения результатов модернизации и эффективности мер во всех отраслях экономики. Системный подход в своем классическом значении предполагает наличие основ- 
ных системных признаков модернизационного процесса: взаимодействующие элементы, интегративное качество, единство назначения, функциональная целостность, консолидированная связь с внешней средой [11], некоторые из которых могут быть исследованы автором в данной статье.

Прежде всего, следует обобщить и уточнить понятие стабильности законодательства с учетом ее двоякой природы воздействия на развитие общества и государства.

Далее выявить и систематизировать факторы, влияющие на стабильность законодательства, с одной стороны, и обозначить точки влияние стабильности законодательства на эффективность реализации процесса модернизации экономики РФ в современных условиях развития общества.

В заключении, на основе системного подхода обозначить ориентиры взаимодействия стабильной правовой основы с эффективными модернизационными процессами в экономике РФ.

\section{Результаты.}

Очевидно, что невозможно вести речь о модернизации экономики страны, без модернизации ее правовой системы, и в частности существующего законодательства. В этом контексте, актуальность приобретают способы сохранения стабильности законодательства без ущерба для модернизационных процессов. Попытка выявления ориентиров взаимодействия стабильной правовой основы с эффективными модернизационными процессами в экономике, неизбежно приводит нас к анализу способов обеспечения стабильности законодательства [5].

Большое влияние на качество нормативных актов оказывает уровень квалификации законодателя, ведь лица, которым народ делегирует право создавать законы, должны обладать высоким уровнем законодательной техники, хорошо понимать процесс правотворчества, и уметь профессионально анализировать экономикосоциальные реалии.

Одним из способов влияния на стабильность законодательства является обеспечение соответствия содержания норм права запросам и потребностям общества. Общественное мнение должно анализироваться как перед созданием нормативных актов, так и в процессе их реализации (через оценку регулирующего воздействия и систему мониторинга правоприменения).

Модернизация экономики требует создания нормативной базы для новых видов экономической деятельности, в этом контексте важно построение непротиворечивого прогрессивного законодательства в области интеллектуальной собственности и стандартизации.

Стабильности законодательства также могут способствовать: закрепление механизмов предупреждения одностороннего расторжения договоров, детализация прав и обязанностей сторон правоотношений в условиях форс-мажорных ситуаций (карантинов, пандемий, самоизоляции), развитие судебного толкования и более активное использование бланкетных норм.

\section{Заключение, выводы.}

В современном быстро изменяющемся мире законодательство должно адекватно реагировать на изменения общественных отношений, одновременно сохраняя определённый уровень непротиворечивости, и тем самым поддерживать баланс между другими элементами системы. Стабильность законодательства имеет существенное значение для осуществления технологической модернизации всех отраслей общественной жизни России, в то же время, задачи модернизации экономики требуют от государства постоянных усилий направленных на минимизацию застойных явлений в правовой системе.

Стабильно развивающееся законодательство, обладающее признаками социальной обусловленности, понятности, непротиворечивости и прогрессивности, может выступить в роли прочного фундамента для внедрения новых технологий во все сферы жизни общества и улучшения инвестиционного климата страны.

\section{Библиографический список}

1. Dzhikiya A.A., Lavrentyeva A. V., Dzhikiya M.D., Kryuchkova M.S. Technological modernization SWOT analysis in conditions of transition to the digital scenario of economic development. - Proceedings of the 32nd International Business Information Management Association Conference, IBIMA 2018 - Vision 2020: Sustainable Economic Development and Application of Innovation Management from Regional expansion to Global Growth 32, Vision 2020: Sustainable Economic Development and Application of Innovation Management from Regional Expansion to Global Growth. 2018. C. 7131-7137. 
2. Большой энциклопедический словарь. URL: https://gufo.me/dict/bes/ (дата обращения: 28.04.2020).

3. Василевич Г.А. Высокое качество и приемлемая стабильность законодательства - важнейшее требование времени // Юридическая наука и практика: Вестник Нижегородской академии МВД России. 2018. № 2 (42). C. 348-353.

4. Давыдова М.Л. Законотворческие риски и проблема стабильности законодательства / М.Л.Давыдова // Юридическая техника. 2019. № 13. URL: https://cyberleninka.ru/article/n/zakonotvorcheskie-riski-i-problemastabilnosti-zakonodatelstva (дата обращения: 28.04.2020).

5. Джикия М.Д. Экономико-правовое взаимодействие в свете технологической модернизации экономики РФ // Вопросы экономики и права № 10 (124). 2018. С.12-16.

6. Карасева И.А. Конкуренция правовых ценностей в практике Конституционного Суда Российской Федерации и конституционных судов зарубежных стран: дис. ... канд. юрид. наук. М., 2014. С. 38-39.

7. Концепция стабильности закона / Под ред. В.П. Казимирчука. М.: «Проспект», 2000. с.12;

8. Литвинова С. Ф. Содержание категории «стабильность» в праве. // Евразийский юридический журнал, № 8. 2012 г. С. $47-51$.

9. Литвинова С. Ф. Стабильность как оценочная категория качества права со стороны общества //Общество и право - 2012 - № 4 (41). С.38-42.

10. Павлов В.И. К вопросу о стабильности законодательства. // Актуальные проблемы юридической науки: мат-лы респ. науч.-практ. конф., Могилев, 18 мая. 2012 г.- Могилев: УО «МГУ им. А. А. Кулешова», 2012 г. С. 310-313.

11. Прангишвили И. В. Системный подход и общесистемные закономерности.-М.: СИНТЕГ.-2000.- С. 22-23.

12. Примаков Д.Я., Дмитриева А.В., Волков В.В., авторский коллектив. Законодательная активность, стабильность законодательства и качество правовой среды: сравнительный анализ постсоциалистических стран (Серия «Аналитические записки по проблемам правоприменения», Май 2010) // СПб: ИПП ЕУ СПб, 2010 г. С. 24.

13. Рыбаков В. А. Стабильность российского законодательства // Право и государство: теория и практика. 2016. № 6(138). C.6-10.

14. Тлехатук А.К. Проблемы обеспечения стабильности федерального и регионального законодательства // Актуальные проблемы теории и практики конституционного судопроизводства. 2017. № 12. С. 274-280. 